\title{
鉄道高架橋を対象とした三次元モデルと 解析ソフトウェアとの連携に関する検討
}

\author{
藤澤 泰雄 1 矢吹 $\quad$ 信喜 2 \\ 1正会員 大阪大学 大学院工学研究科 環境・エネルギー工学専攻 博士後期課程 \\ ( ₹565-0871 大阪府吹田市山田丘2-1) \\ E-mail: fujisawa@yachiyo-eng.co.jp \\ 2正会員 大阪大学教授 大学院工学研究科 環境・エネルギー工学専攻 \\ ( ( 565-0871 大阪府吹田市山田丘2-1) \\ E-mail: yabuki@see.eng.osaka-u.ac.jp
}

\begin{abstract}
土木分野での三次元モデルの利用は，設計・施工などの各分野の中の一部で利用されているにすぎない. 特に設計においては解析が重要な位置を占めているが，発注者も受注者も三次元モデルに慣れていないた め三次元モデルの利用は進んでいない。本研究では, 鉄道高架橋を対象に, 三次元モデルから二次元解析 ソフトウェア用の解析データと三次元解析ソフトウェア用の解析データを出力することにより三次元モデ ルと解析ソフトウェア, IAI日本が発表しているST-BRIDGEとの連携方法を示し，その課題を検討した.
\end{abstract}

Key Words : 3D Models, design, product model, viaduct, BIM, ST-BRIDGE

\section{1. はじめに}

建築分野ではBIM(Building Information Modeling)の概念を 実現するために様々な努力が行われている. BIMにおい ては，三次元プロダクトモデルが構造物の設計・施工お よび維持管理のライフサイクルにわたって利用されるこ とをめざしている. 土木分野では，IFC-BRIDGE ${ }^{1)}$ やIFCShield Tunnel' ${ }^{2}$ などが開発されているものの，全体として はBIM概念の採用はあまり進んでいない. 土木分野にお ける三次元モデルの利用は，施工時における複雑な配筋 部分の干渉チェックや設計時・施工時の住民への説明な どその時に必要とされる現実的な問題を解決するために 利用されており，設計と施工が連携した利用などフェー ズ間を渡った利用はあまり行われていない.これは，現 在の入札システムが設計と施工を分離したシステムとな っているためであり，その結果が，土木分野でのライフ サイクルに渡る三次元プロダクトモデルの流通を妨げて いると考えられている3).

土木構造物の発注の多くは，国土交通省や都道府県な どの公共団体等が行っている。これらの発注者の多くは， BIM，三次元プロダクトモデルやこれらの統合に関する 知識をあまり持っていないこともあり，三次元の利用を ためらうことが多い. また, 設計者も従来の二次元設計
における作業に慣れており，設計ツールなども整備され ているため二次元モデルに基づいた設計のまま変更しよ うと考えていないし，その余裕もないのが現状であろう. 今後, 生産性を向上し設計段階・施工段階での単純なミ スを防止するためには，受発注者双方がBIMの必要性を 理解していくことが重要であると考えられている. そし て，こうした現状を変えていくためには，従来の設計手 法を，三次元モデルを中心とした設計手法に変更するた めの方策と，その長所，短所を明確にした新しい設計を 提案してくことが求められている.

こうした状況を受けて，国土交通省では，営繥分野で BIMの利用を開始した。さらに，2012年7月から土木に も BIMの概念を取り入れるためConstruction Information Modeling (CIM)として三次元モデルの活用を始めるため の検討会を発足した。この検討会での結果を受けて実証 実験を開始する予定であり，これにより発注者，受注者 など関係者のBIM (CIM)に関する理解が進むことが期待 されている.

CIMが開始されたとは言え，国内の土木分野では，実 際にはまだほとんど三次元モデルを利用していないため， どのように利用できるのかが理解されておらず検証もさ れていない. 既往の研究でも, 三次元プロダクトモデル の開発・適用に関する事例は多いが，プロダクトモデル 
と土木構造物の解析に関して研究されている事例は見当 たらない，建築分野では，三次元CADで建物モデルを 作り, IFCで出力したファイルを, 熱環境解析ソフトウ エア（例えば，環境シミュレーション社のWindPerfect DX）に入力すると，建物などのデータがそのまま解析 に使われている事例がある. CIMを推進するためには, プロダクトモデルとしてどのように三次元モデルを作成 しどのような形で利用し，その結果を次のフェーズに連 携していくかが重要なテーマである、筆者らは以前, 設 計で作成した三次元モデルの適用性を示寸ために，三次 元設計モデルの設計・施工一の適用事例を示し数量算出, 施工計画に適用できることを示しだ+. 設計の現場では, 三次元設計を普及寸るには設計業務の中心となっている 構造解析において三次元モデルをどのように用いていく かが次の課題として考えられている.

本研究では, 設計における構造解析を対象に, 三次元 モデルと解析ソフトウェアとの連携方法について検討す ることとした. 対象とした構造物は, RC鉄道高架橋で, 解析ソフトウェアはJRSNAP（鉄道総合技術研究所）と DARS(株式会社 構造計画研究所)である。JRSNAP と DARSは，鉄道構造物を対象として，材料と地盤抵抗の 非線形性を考慮した平面骨組静的非線形解析ソフトウェ アであり, 解析対象は主として直接基礎形式または杭基 礎形式を持つラーメン高架橋, 橋台および橋脚である.

\section{2. 設計時における構造解析の現状}

二次元モデルで設計する場合は，図-1に示すように線 路方向と線路直角方向のいくつかの断面で解析モデルを 設定するが，二次元モデルであるため，これらは相互に は直接連携していない．このため，どちらか一方向だけ を修正して，他方を修正し忘れるなどのミスが発生しや すい．特に複雑な構造物では，作成する図面数は100枚
以上に及ぶ場合もあり，修正ミスが発生することが多い． 解析に三次元モデルを用いた場合，流れ自体は同じであ るが，三次元モデルを修正すると線路方向と線路直角方 向双方に関連する部材は自動的に変更されるため, この 三次元モデルから二次元解析モデルを作成寸れば修正に よる断面相互の修正ミスはほとんど発生しないはずであ る.また，三次元モデルでは不整形なラーメン高架橋な ども検討が可能であり, 従来の二次元モデルでは評価で きなかった地震時のねじれなどの複雑な挙動も評価でき るなど, 今後複雑化する構造物の解析には三次元解析は 必須であり，実際，道路橋などでは耐震解析は三次元解 析が標準となっている.

こうした状況においても設計の現場では三次元モデル の利用が進んでいない.この主な理由は，(1) 三次元モ デルを扱えるソフトウェアが少なく，高価であったこと， (2)二次元設計のためのツールが充実しており，設計者 はこれを用いることに慣れている，(3) 受発注者双方が 二次元設計の結果の評価に慣れているが，三次元解析の 結果をどのように評価してよいか十分に理解できていな いためなどである.

確かに，現状で三次元設計を行うためには，(1) 三次 元モデルを作成， (2) 三次元モデルから三次元解析モデ ルへの変換, (3) 三次元解析結果の評価, (4) 三次元解析 結果から二次元図面の作図 といった手順を行い, これ らのモデルの作成手法・評価などを再度習得しなければ ならず手間がかかる。 また, 現状で利用されている三次 元解析ソフトウェアは, その解析ソフトウェアのための モデル作成ツールが付属しているが，操作方法などは固 有で, データフォーマットも独自形式であり, 三種類の 三次元解析を行うためには三種類のソフトウェアのモデ ル作成ツールの使用方法を学習しなければならない。こ うした課題も普及を阻害している原因と考えられる.

こうした中で，BIMの進展により汎用的な三次元モデ ルを作成できるツールが登場しており, buildingSMART

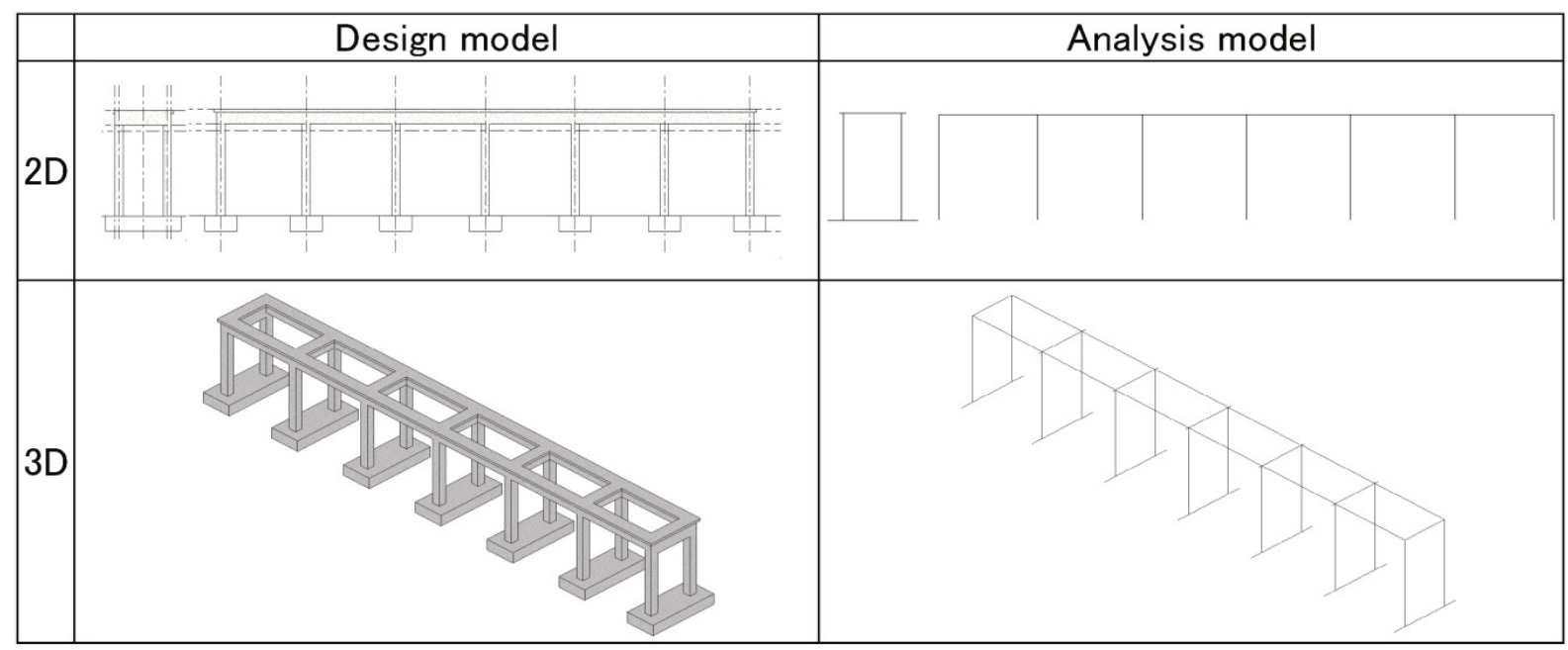

図-1 設計モデルと解析モデル 
が提唱するIFCがISOとして国際標準となる予定であり三 次元モデルの標準化も進んでいる．知吹ら ${ }^{5}$ は，PC橋梁 の三次元プロダクトモデルを開発しており，今後もこう した土木構造物のプロダクトモデルの開発と普及も促進 されると思われる. 一方で, 既往の三次元構造解析プロ グラムは独自のモデル作成ツールを持っており，これら の解析ソフトウェアもIFCに対応するのが望ましいと思 われるが，上記のように土木構造物のプロダクトモデル は開発途中であり対応には時間がかかる。こうした中で, IAI日本構造分科会では，構造モデルの普及活動と実証 実験結果の展開およびアグリメント作成とソフトウェア へのIFC実装環境整備のために，国内構造関連アプリケ ーションの連携用標準フォーマット「ST-BRIDGE」を開 発しているす． ST-BRIDGEは，XML形式を採用しており， IFCよりも形式が簡易なため扱いやすい. ST-BRIDGEは, 既に福井コンピュータ社製の建築用三次元CADソフト ウェアGLOOBEに実装されているなど一部の製品間では 連携も始まっており, 汎用的な三次元モデル作成ツール で作成した三次元モデルと解析ソフトウェアが連携すれ ば，設計者の利便性は向上寸るものと思われる(図-2).

\section{3. 三次元モデルと解析ソフトウェアの連携方法}

\section{（1） 対象とした解析ソフトウェアの特徵}

鉄道分野の設計では，設計者は，認証された解析ソフ トウェアの利用が義務付けられている. 本研究では三次 元モデルデータから出力する解析ソフトウェアとして二 次元ソフトウェアは鉄道総合技術研究所社製のJRSNAP を, 三次元ソフトウェアは構造計画研究所社製のDARS を対象とした.JRSNAPとDARSは鉄道構造物等の設計に 用いられている鉄道構造物等設計標準・同解説 (コンク リート構造物 平成16年改訂），鉄道構造物等設計標 準・同解説（耐震設計 平成11年制定）に準拠したプロ グラムである. DARSはJRSNAPの三次元版として開発さ れているため, 解析に必要とする情報は非常によく似て いるが，DARSでは三次元モデルを用いることによりス ラブへの直接的な荷重配置により複雑な荷重計算, 荷重

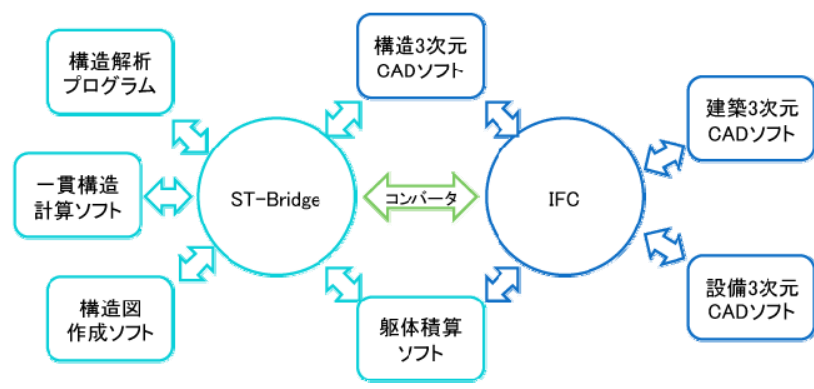

図-2 ST-BRIDGEでの連携の考え方
分担計算の省略や，1モデル2方向に解析・照査すること により解析ケース数, 作業量を大幅に軽減できるなどの 特徵がある。

JRSNAPは，地震時の動的解析が行えるなど一般的解 析ソフトウェアより機能が多いが，こうした機能に対応 寸るため入力パラメータが他のソフトウェアよりも複雑 となっている.

\section{(2) 三次元モデル作成ツールと変換ソフトウェア開発 環境}

三次元モデルの作成には，Autodesk社製のRevit Structure 2012 （以下 RSTとする）を用いた，RSTでは，Familyと 呼ばれる部品を事前に作成しておき，この部品を組み合 わせることにより簡易にモデルを作成することが可能で ある. RSTで作成した三次元モデルからJRSNAPおよび DARS の変換ソフトウェアは，RSTのSoftware Development Kit (SDK) とMicrosoft社製のVisual Studio 2010を用いて RST上で稼働するアドインソフトウェアとして作成した

\section{（3）解析ソフトウェアのデータ構造と解析モデル作成 上の特徵}

本検討で対象とする解析は, 構造解析であり, 解析に 必要な事項は, 解析フレーム (軸線) とフレームを構成 する部材の断面形状，部材特性（材料強度，配筋など）, 荷重, 境界条件(支点条件, 地盤条件), 解析制御デー夕 である.JRSNAPではこれらの解析データを表-1に示す ようなブロックと呼ばれる単位で分類しておりデータの 先頭はヘッディングカードをセットする. 本研究では解 析に必要となる表-1の太枠の必須項目と適用断面データ を変換対象とした。

モデル作成上の特徵は，以下の通りである.

・部材ごとに断面形状の他，鉄筋の配置位置を入力す る必要がある(図-3).

・JRSNAPでは，梁，柱部材では図に示すような位置 で岡域と非線形性を考慮するための $10 \mathrm{~mm}$ 幅のばね 部材を設定する必要があり，節点を追加しこの部 材を作成する必要がある(図-4).

表-1 JRSNAPの解析データ

\begin{tabular}{|c|c|c|c|}
\hline プロックデー夕番号 & へディングカート & データの内容 & 入力 \\
\hline BLOCK1 & START & タイトルデータ & 必須 \\
\hline BLOCK2 & DIMENSION & 構造基本データ & 必須 \\
\hline BLOCK3 & $\mathrm{DA}$ & 非線形解析制御データ & 必須 \\
\hline BLOCK4 & JOINT & 節点座㩰データ & 必須 \\
\hline BLOCK5 & MEMBER & 要素宁一タ & 必須 \\
\hline BLOCK6 & SUPPORT & 支点デー夕 & 必須 \\
\hline BLOCK7 & $\mathrm{MF}$ & 材料非線形特性テー夕 (固定值入力) & オプション \\
\hline BLOCK8 & $\mathrm{DL}$ & 材料非線形特性自動設定用デー夕 & オプンシン \\
\hline BLOCK8 & $\overline{A P}$ & 適用所面データ & オブション \\
\hline BLOCK9 & LOAD & 俩重テー夕 & オプンシン \\
\hline BLOCK10 & $\mathrm{PP}$ & 有効抵抗土圧デー夕 & オプション \\
\hline BLOCK11 & ED & 地盤変位データ & オプション \\
\hline BLOCK12 & DI & 強制复位デー夕 & オプション \\
\hline BLOCK13 & KG & 杭基磷設定用データ & オプション \\
\hline BLOCK14 & OT & 地盤変位量連携用データ & オプション \\
\hline BLOCK 15 & & 解析の実行開始 & 必須 \\
\hline
\end{tabular}




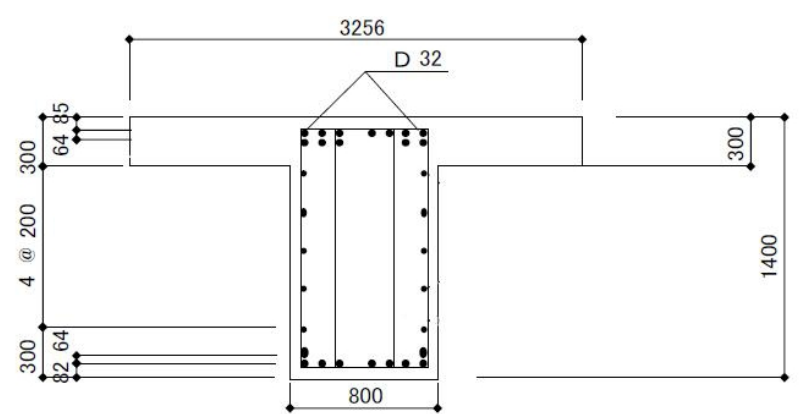

図-3 鉄筋の配置

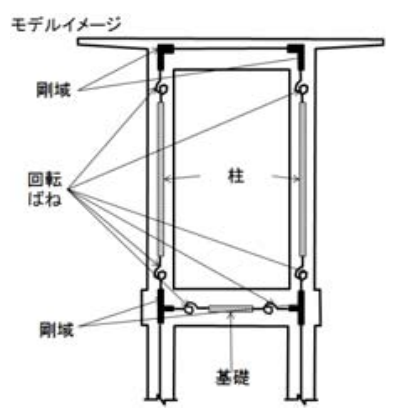

図-4 剛域と回転ばねの設定

\section{(4) 三次元モデルのデータ構造}

RSTで作成されるモデルは，一つ一つがFamilyと呼ば れる部品で作成されており，この部品に属性情報が格納 されている．この部品を組み合わせて全体のモデルを作 成する. RST SDKでこうした属性情報にアクセスするた めのAPIが提供されている. RST APIを用いると, Family
表-2ＲSTモデルのデータ構造

\begin{tabular}{|l|l|l|}
\hline \multicolumn{1}{|c|}{ 分類名 } & \multicolumn{1}{|c|}{ 内容 } & 值がセットされる時期 \\
\hline Category & 要素型を識別するクラス & Family作成時 \\
\hline Location & 配置情報クラス & モデル作成時 \\
\hline Materials & 材料特性クラス & Family作成時 \\
\hline Parameters & 属性クラス & Family/モデル作成時 \\
\hline AnalyticalModel & 構造解析クラス & モデル作成時 \\
\hline
\end{tabular}

からは，表-2に示すような情報を取得できる，変換プロ グラムでは，これらの情報をRSMemberと Nodeという 2 つのクラスに格納して利用するものとした. RSMembaer は，表-2のCategory， Parameters とAnlyticalModelを部材ごと にまとめたもので, NodeクラスはLocationを中心に節点 座標データを格納している。こうすることにより部材ご とに各種の情報にアクセスすることが可能となる．また 部材の断面情報や各種の属性は三次元モデルでは Parametersから取得できるため, 取得した属性を形状, 配筋などの分類ごとにRSMemberのサブクラスとした.

\section{(5) 解析のためのモデル化の検討}

解析ソフトウェアのデータモデルと三次元モデルの構 造から，作成すべき三次元モデルをどのように作成すべ きかを検討した。

節点, 要素データは, AnalyticalModelから情報を取得 できるため, 構造解析のための部品を用いてFamilyを作 成する必要がある。この節点，要素データから図-4に示

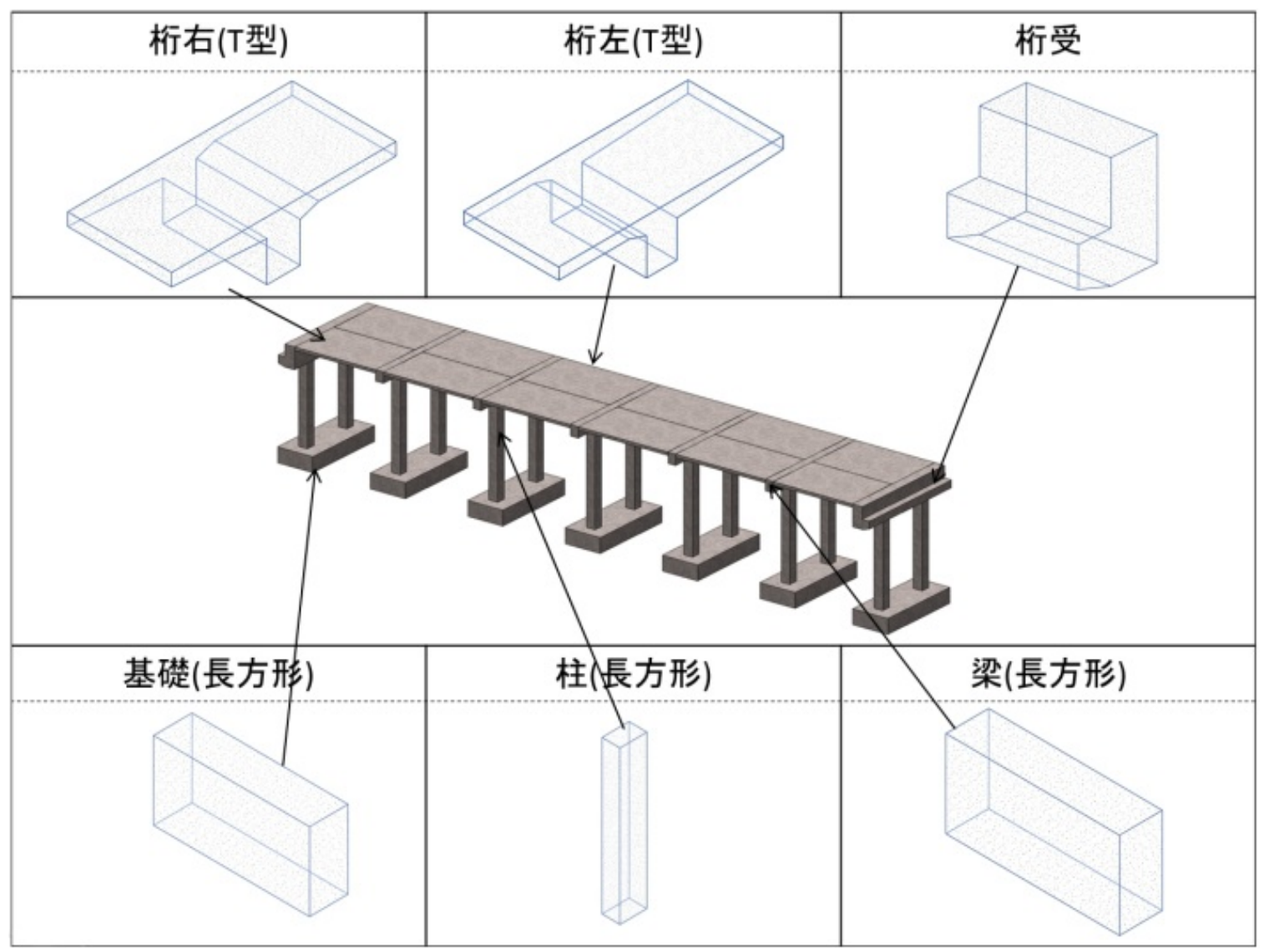

図-5 高架橋の三次元モデル 
した剛域，ばね部材を追加するための新しい節点位置は 内部で計算可能である。 また，上部のT型梁は左右で形 状が違うため, 別々のFamilyとした.

当初，配筋データもモデル化できるため，モデルデー タとして作成して検討を始めたが，配筋モデルを作成す ると非常にデータ量が多く負荷が高いため，属性情報と

してFamilyに追加することとした.

境界条件には，支点情報の他，地盤の物性を設定する 必要があるため，これも属性データとして追加すること とした．このように検討した結果，図-5に示すモデルを 作製した.

\section{(6) 変換ソフトウェアの機能検討と作成}

対象とするモデルの構成を元に変換するソフトウェア の機能の検討を行った. 变換対象は, 表-1に太枠で示す 必須項目とモデルデータから取得できる形状データとし た.

変換ソフトウェアの機能として考慮した点とその内容 は以下の通りである.

・単純ミスを起こさないように可能な処理は内部で行 うこと

JRSNAPでは, 線路方向, 線路直角方向の各々の解析 を行う際の梁の解析線分の高さは，断面の図芯位置と定 められている．この際，鉄筋は無視しているが，断面形 状を変更するとJRSNAPのモデル形状も変更する必要が ある. このため, 部品の形状から梁の図芯高さや断面2 次モーメントも内部で計算できるようにしておくことに より自動化とミスの軽減を図った。

・RSTのアドインであるが，設定などはわかりやすく 入力できること

属性情報はRSTの機能として図-6のように設定できる が，設定しやすくするために図-7のようなダイヤログを 作成している.

DARSでは，解析データを作成するために，スクリプ 卜機能というテキスト形式での操作手順ファイルを作成 しておくと，このファイルを読み込むことにより解析モ

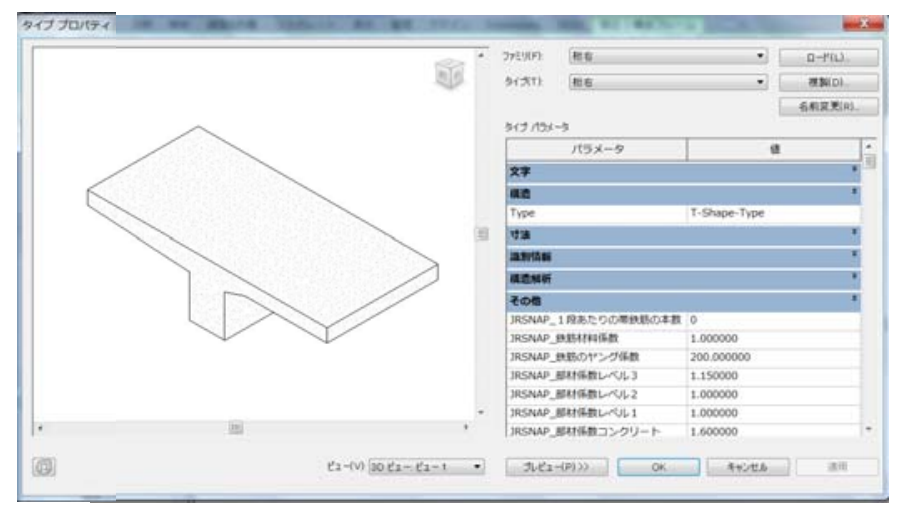

図-6ＲSTのFamilyとプロパティの設定(T型梁)
デルを作成することが可能であり変換ソフトウェアは, このスクリプトファイルを作成するものとした．変換内 容は，JRSNAPと同様に形状および部材断面に関する部 分とした. DARSは二次元解析ソフトウェアである JRSNAPを三次元化したものであるため，必要とするパ ラメータはほぼ同じである。軸方向鉄筋の配置に関して はJRSNAPでは，配筋位置は配置高さだけを入力すれば 良かったが，DARSで水平位置も必要であるため内部で 配置を計算した. このように, 変換ソフトウェアの作成 は二次元用に設定した各種の属性を用いることにより比 較的簡単に作成が可能であったため，作成時間は一週間 ほどであった，また，事前にJRSNAPで各種の機能を理 解していたことにもよるが，形状データはその形式をほ とんど変更する必要がないため, 三次元解析モデルに変 換する方が明らかに簡易であった．図-8に変換データを DARSで入力して検証した結果を示寸.

\section{(7) 変換ソフトウェアの評価}

現状ではまだ三次元モデルを用いて設計を開始してい ないため, この変換ソフトウェアでどの程度作業が効率 化するかは評価できていない.

現状での二次元モデルを用いて鉄道高架橋を設計する ための一般的な手順を図-9に示す. 図-9に示寸作業項目 の括弧内は一般的な作業日数を示している. 荷重計算, 地盤定数設定作業は，三次元モデルを利用しても作業に 変更はないため, 三次元モデルを利用することにより効 率化されるのは，図-8の太枠で示している作業が主体と なる. したがって，三次元モデルを利用して解析データ を出力する場合は，解析までの16日間のうち三次元モデ ルを作成する太枠の6日間の作業が効率化すると思われ る. その他に，モデルを変更した場合の修正忘れ等の単 純ミスの防止や，本検討では対象としていないが荷重の 作成なども効率化できると考えている.

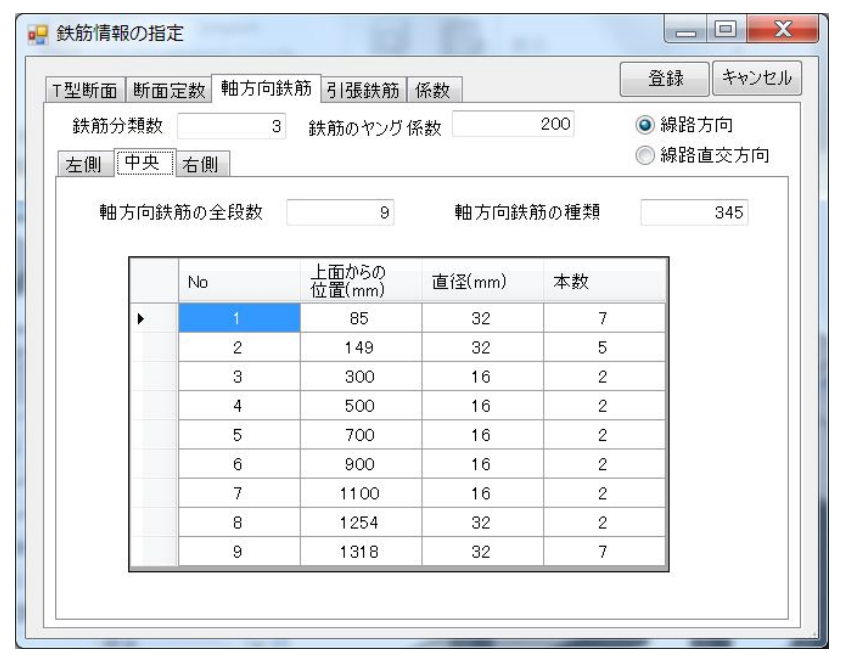

図-7＼cjkstart配筋位置のダイアログ 


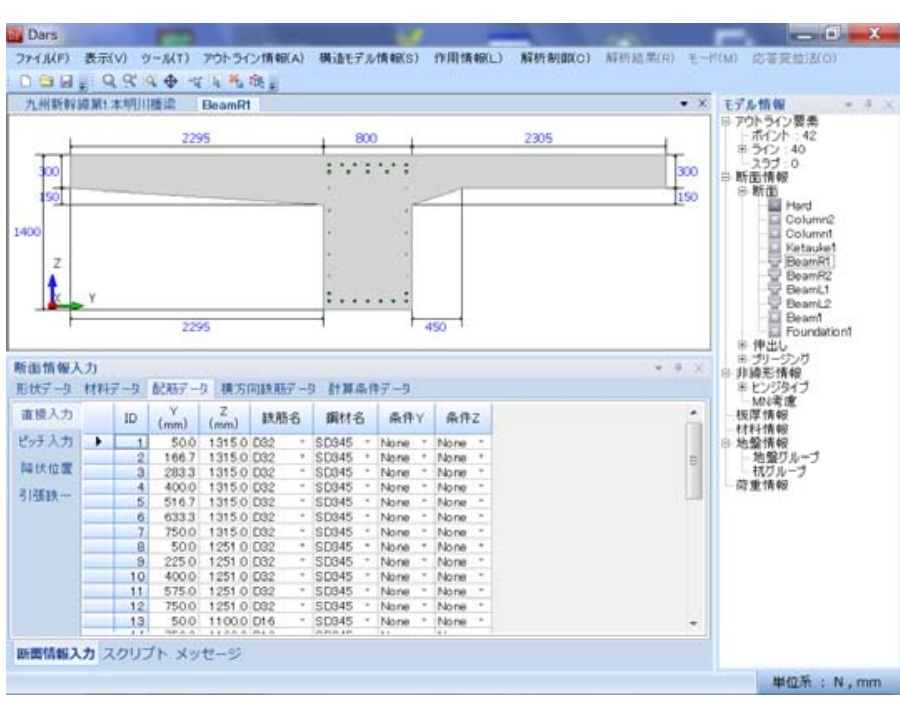

(a) 梁断面( $(\mathrm{O}$ 型)

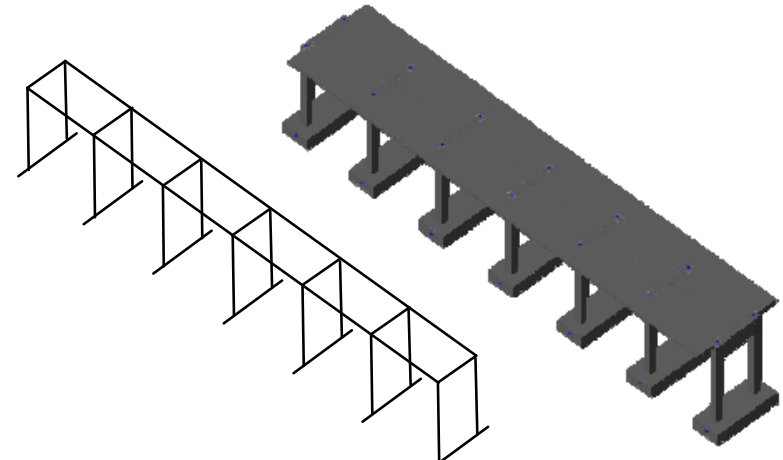

(b) 解析モデル

(c) 形状モデル

*Inser tPoint Point37 23009. 22729, -6005. 513612, -1400 *InsertPoint Point38 32534.22729, 2494. 486388,-1400 *InsertPoint Point39 32534.22729,-6005.513612 - 1400 *InsertPoint Point40 - 26515. 77271. 2494. 486388, - 1400 *InsertPoint Point41 -26515.77271, -6005. 513612, - 1400 ラインの作成

柱

*Insertlines 3 C1 Point0 Point1

*InsertLines 3 C2 Point2 Point3

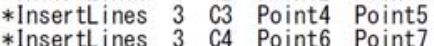

(d) DARS 用スクリプトの例

図-8 DARSによる表示

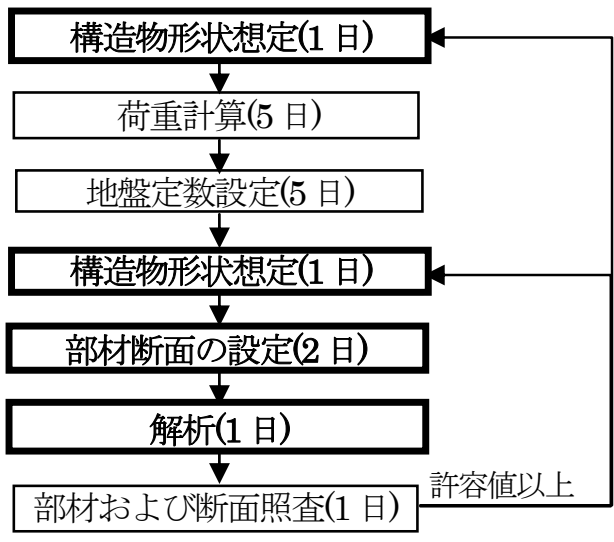

図-9 設計における解析の流れと日数

\section{ST-BRIDGEへの対応}

前述のように解析のための標準フォーマットしてSTBRIDGEが開発されており最新版はVer1.0である．実際 に実装されたソフトウェアが発表され実用化が開始され たため前述の三次元モデルをST-BRIDGEのフォーマット 形式に出力してGLOOBEで読み取りが可能かを検証した。

\section{(1) ST-BRIDGEの形式}

ST-BRIDGEのフォーマットはXML形式で標準的な夕 グは表-3のようになっている．建築分野を中心にしてい るため軸，階という土木分野では使用しない呼び方が使 われているが，軸は橋脚位置，階はレベルとして考えれ ばよい。

\section{(2) ST-BRIDGE フォーマットへの変換}

ST-BRIDGEフォーマットへの変換は，基本的には DARSの出力とほぼ同じように節点データは, Nodeクラ
スから, 部材データと断面データはRSMemberクラスか ら出力している。軸はX,Y軸として固定情報で，階は NodeクラスからZ值の最大值と最小值の情報を出力した. ここで問題となったのは，T型断面の取扱いであった. 土木分野では梁，柱として荷重を負担すると考える場合 が多いが，建築分野では柱間が広いため梁・スラブ構造 として考えることが多い. ST-BRIDGEは梁・スラブとし ての取扱いが主体で，本研究で対象とした鉄道高架橋の T型断面を直接扱うことができなかったため，便宜的に T型断面，桁受けは矩形構造として出力した(図-10). 図11にST-BRIDEGで変換結果の一部を，図-12にGLOOBE で表示した結果を示す.

このように土木分野と建築分野でほぼ同じものを対象 とする場合に，基本的な考え方が違う場合があるなどは 今後の検討課題である.

表-3 ST-BRIDGEのタグ

\begin{tabular}{|l|l|}
\hline \multicolumn{1}{|c|}{ タグ } & \multicolumn{1}{c|}{ 内容 } \\
\hline$\langle$ StbCommon $\rangle$ & 建物の共通情報を表す \\
\hline$\langle$ StbModel $\rangle$ & 節点·部材の情報(位置·断面)を表す \\
\hline$\langle$ StbNodes $\rangle$ & 節点 \\
\hline$\langle$ StbAxes $\rangle$ & 軸 \\
\hline$\langle$ StbStories $\rangle$ & 階 \\
\hline$\langle$ StbMembers $\rangle$ & 部材 \\
\hline$\langle$ StbSections $\rangle$ & 断面 \\
\hline$\langle$ StbFromlfc $\rangle$ & Ifcデータを表す(敷地·複雑な形状用) \\
\hline
\end{tabular}

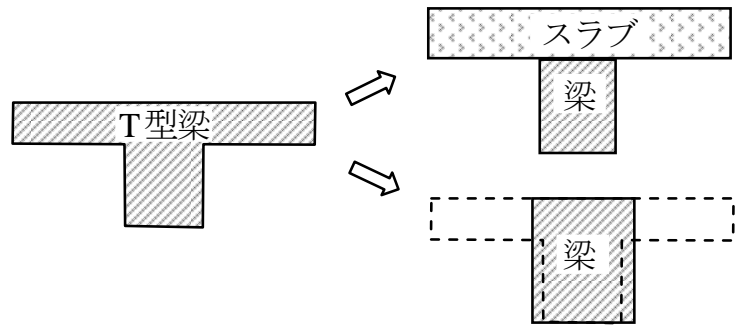

図-10 T型梁の対応 
<? xml version $=" 1.0$ " encoding $=$ "shift_jis" standalone="yes" ?>

<ST BRIDGE version="1.00.000"

<StbCommon global1D="ERB*352-10001S" project_name="" app_name="Revit2012 $<$ StbModel $>$

<StbNodes

<StbNode id="0" x="-16990.773" y="-4455.514" z-"-1400" />

SStbNode id="1" $x="-16990.773 " y="-4455.514 " z=" 10000 " />$

SStbNode id $=" 2$ " $x="-16990.773^{n} \quad y=" 944.486 " z=" 1400 " />$

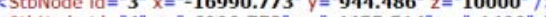

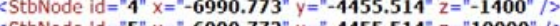

$+<$ Stbaxes $>$

+ <StbStories>

$<$ StbMembers >

$=$ "Column21" IdNode bottom=" 0 " IdNode_top="1" rotat $<$ StbColumn id="2" name="Column 22 "IdNode_bottom="2" idNode_top=" 3 " rotat $<$ StbColumn Id =" 3" name="Column23" IdNode_bottom = "4" IdNode_top=" "5" rotat $<$ StbColumn id $=4$ " name $=$ "Column24" idNode_bottom $=" 6$ " idNode_top $="$ " rotat $<$ StbColumn id $=" 5$ " name $=$ "Column25" idNode_bottom $=" 8$ " idNode_top $=" 9$ " rotat $<$ StbColumn id="6" name="Column26" idNode_bottom="10" idNode_top $=" 11$ " ro $<$ StbColumn id ="7" name="Column27" idNode_bottom="12" idNode_top $=" 13^{\prime \prime}$ ro $<$ StbColumn id $=" 8$ " name $=$ "Column28" idNode_bottom $=" 14$ " idNode_top $=" 15 "$ ro $<$ StbColumn id ="9" name = "Column29" IdNode_bottom="16" IdNode_top="17" ro 図-11 ST-BRIDGEに変換した結果の一部

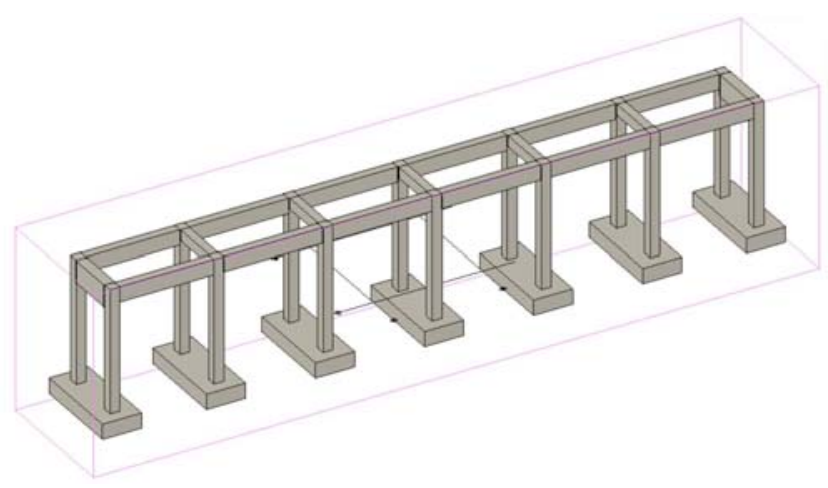

図-12ＧLOOBEで表示した結果

\section{5. まとめ}

\section{(1) 結論}

本研究では，三次元モデルを用いて解析ソフトウェア と連携するためのモデルの作成方法，パラメータの設定 について検討し，解析データを作成する変換ソフトウェ アを作成した。

その結果として以下のことが分かった。

・構造フレーム形状の取得，変換は，三次元モデルの 節点，要素データを取得することで対応可能なた め比較的簡単に行える

・ $\mathrm{T}$ 型断面・桁受け・ハンチ部のような複雑な形状の 断面取得は，モデル側と解析側でその形状(T型な ど)を特定できる機能がないと難しい

・配筋のモデル化も可能であるが，鉄筋径，位置など を属性として与えることで簡易に連携できる

・特定の解析のためには，非常に多くの属性を追加す る必要がある

・変換ソフトウェアの作成には，三次元モデルと解析 ソフトウェア双方の知識が必要で，作成には非常 に手間がかかる

今後の三次元設計を推進していくためには，やはり三
次元解析を行っていく必要がある。しかし前述のよう に，受発注者ともに三次元モデルを利用するためのハ 一ドルが高い。また，一般的に三次元モデルで解析し た結果を二次元モデルで解析した結果と比べると，構 造物の応力レベルでは三次元モデルで解析したほうが 小さくなる傾向にある。 このため，三次元解析に慣れ ていない技術者はその結果をどのように判断してよい かがわからない。これから三次元設計を進めていく過 渡期においては，二次元の結果と三次元の結果を比較 してその相違をどのように評価していけばよいかを検 証していく必要があり，そのためにも三次元モデルと 二次元解析との連携を当面は続ける必要があると考え る.

\section{(2) 今後の課題}

現状での課題として三次元モデルを作成するツールや， 三次元解析ソフトウェアは普及し始めているが，従来か ら行っている二次元モデルを利用した設計の進め方に受 注者も発注者も慣れており，新しい三次元モデルを利用 することは難しく，また手間がかかると考えており適用 を開始していない：このため，三次元モデルはなかなか 利用されず，従来手法が使われ続けている．今後，三次 元モデルの利用が進んだ場合でも，二次元と三次元で解 析した結果の比較を行うなど，三次元解析結果をどのよ うに評価していくかが受発注者の今後の課題となる.

また，今後普及していくと思われる多くのモデル作成 ツールごとに独立した解析ソフトウェアとの変換ソフト ウェアを開発していくには非常にコスト(時間)がかかり， これも普及の妨げとなることが考えられる．図-2に示す ような解析データの連携のためのIFCやST-BRIDGEなど が普及すればこうした課題も解消されると思われる.

しかし，構造解析では同じような構造物でも建築系と 土木系でスラブ構造と考えるか梁構造物として捉えるか など，従来の二次元解析との整合性なども考慮に入れて， 今後の三次元解析のあり方も議論していく必要がある.

今後は，対応できる断面形状，非線形パラメータの入 力の追加など機能を向上させ，実際の設計一適用して効 率化の検証を行い，三次元モデルから二次元解析，三次 元解析のどちらでも利用できる環境や標準フォーマット の利用などを通して，三次元モデル設計の普及方法を検 討する予定である.

謝辞 : 本研究の遂行に際して，三次元解析ソフトウェア DARSを提供していただきました株式会社 構造計画研究 所，ST-BRIDGEのサンプルを提供いただきました福井コ ンピュータ株式会社の関係者の皆様にお礼を申し上げま す. 


\section{参考文献}

1) Yabuki, N., Lebegue, E., Gual, J., Shitani, T. and Li, Z.: Intemational Collaboration for Developing the BRIDGE Product Model "IFCBRIDGE", Proc. of the Joint Intemational Conference on Computing and Decision Making in Civil and Building Engineering, Montreal, Canada, 1927-1936, 2006.6.

2) Yabuki, N.: Representation of caves in a shield tunnel product model, Proc. of the 7th European Conference on Product and Process Modelling, Sophia Antipolis, France, CRC Press, 545-550, 2008.9.

3) Yabuki, N.: Toward Adoption of Virtual Construction in the Infrastructure Domain, Joumal of Society for Social Management Systems, SMS10-160, 2010.
4) 藤澤泰雄，矢吹信喜，五十嵐善一，吉野博之 : 鉄道高架 橋を対象とした三次元設計モデルの積算・施工への利用, 土木学会論文集 F3, Vol. 67 No. 2, pp. 8-17， 2011.

5) 矢吹信喜, 志谷倫章 : PC 橋梁の 3 次元プロダクトモデルの 開発と応用，土木学会論文集，No.784/VI-66，pp.171-187， 2005.

6) IAI 日本支部構造分科会ホームページ, http://www.buildingsmart.jp/meeting/structure.php.

(2012. 10. 17. 受付)

\section{THE COOPERATION BETWEEN A 3D MODEL AND ANALYSIS SOFTWARE FOR RAILWAY VIADUCTS}

\section{Yasuo FUJISAWA and Nobuyoshi YABUKI}

Much effort is underway to realize the concept of Building Information Modeling (BIM) in the building industry. However, in the civil infrastructure domain, the BIM concept has not been adopted yet in practice because few engineers are accustomed to 3D models. As the interaction between 3D models and structural analysis software packages is important in the design phase, two structural analysis software packages for railway viaduct were selected to investigate the linkage between 3D models and the packages. Furthermore, a method of the interaction with ST-BRIDGE, which has been developed by the Structural Group of buildingSMART Japan was demonstrated. Finally, issues related to 3D modeling were discussed. 